\title{
Sistem Pakar Diagnosa Penyakit yang Disertai Demam Menggunakan Metode Naive Bayes Classifier
}

\section{Expert System for Diagnosting Disease with Fever Using Naive Bayes Classifier Method}

\author{
Eko Rantoso', Ozzi Suria² \\ ${ }^{1,2}$ Program Studi Sistem Informasi, Fakultas Teknologi Informasi, Universitas Mercu Buana Yogyakarta \\ J1. Wates Km. 10 Yogyakarta, 55753, Indonesia \\ Email: eko.rantoso@gmail.com¹, ozzisuria@mercubuana-yogya.ac.id²
}

\begin{abstract}
ABSTRAK
Banyak penyakit manusia yang ditandai dengan gejala demam, misalnya penyakit tipus, ISPA, dan cacar air. Ukuran suhu tubuh yang naik akibat demam untuk setiap penyakit juga bervariasi. Banyaknya ragam penyakit yang disertai dengan variasi suhu tubuh akibat demam ini seringkali membuat penderita mengalami kebingungan mengenai jenis penyakit apa yang dialami saat ini. Dalam penelitian ini, penulis mencoba untuk membuat sistem pakar yang dapat digunakan untuk membantu memberikan diagnosa penyakit dengan gejala utama demam disertai dengan gejala-gejala lain. Penyakit yang digunakan sebagai objek penelitian adalah tipus, ISPA, cacar air, diare, gondongan, dan radang amandel. Data yang digunakan sebagai bahan penelitian ini diambil dari salah satu klinik kesehatan dan akan diolah dengan menggunakan metode Nä̈ve Bayes Classifier. Sistem ini akan memberikan informasi mengenai jenis penyakit yang diderita pasien berdasarkan pada gejala-gejala penyakit yang dialami oleh pasien sebelumnya. Berdasarkan 27 data pemeriksaan pasien yang diambil dan diuji dengan sistem serta telah divalidasi oleh ahli pakar, sistem memiliki tingkat akurasi sebesar $96,3 \%$ dalam memberikan diagnosa penyakit.
\end{abstract}

Kata kunci: Sistem Pakar; Naive Bayes Classifier; Penyakit dengan Demam

\begin{abstract}
There are many human diseases which has symptoms of fever e.g typhoid, ARI, and chickenpox. The increased body temperature because of the symptoms of fever also varies. This fever symptoms sometimes makes the patients confused about what kind of disease they suffered from. In this research, the author tries to create expert systems which can be used to help diagnosing disease with fever as the main symptom and also followed with other possible symptoms as well. The diseases which were used as research objects are typhoid, ARI, chickenpox, diarrhea, mumps, and tonsilits. This research uses data from a health clinic. Data will be processed using Nä̈ve Bayes Classifier method. The system will provide information about the disease based on the diagnosis result and symptoms experienced by the prior patients. Based on 27 examination data of the patients which already validated by the expert, the system has $96.3 \%$ accuration rate in providing diagnosis of the disease.
\end{abstract}

Keywords: Expert system; Naive Bayes Classification; Disease with fever symptom

\section{PENDAHULUAN}

Terganggunya kesehatan secara umum disebabkan karena terjadi ketidakseimbangan tubuh, menurunnya imunitas, dan sistem metabolisme yang terganggu. Munculnya gejala penyakit tersebut terjadi karena daya tahan dan sistem kekebalan tubuh setiap manusia yang berbeda. Akibat adanya penyakit yang menyerang tubuh, setiap aktivitas yang dikerjakan menjadi terhambat (Yuliarti, 2009).
Manusia yang terserang penyakit akan ditandai dengan munculnya beberapa gejala penyakit yang khas. Salah satu gejala awal yang umum terjadi adalah demam yang tinggi. Demam adalah suatu kondisi disaat suhu badan menjadi lebih tinggi daripada biasanya, atau suhu diatas $38^{\circ} \mathrm{C}$. Banyak orang tidak memahami jenis penyakit yang dialaminya, hal tersebut karena munculnya gejala demam dapat menyebabkan beberapa jenis penyakit. 
Sehingga untuk mengindikasi jenis penyakit dengan gejala demam, kita harus mengetahui gejala-gejala lain yang menyertainya (Sugani \& Priandarini, 2010).

Berdasarkan hal tersebut, diperlukan sebuah sistem guna mengidentifikasi jenis penyakit yang disertai demam berdasarkan gejala-gejala lain yang muncul. Sehingga dapat membantu dalam proses diagnosa dan penanganan lebih lanjut. Sistem yang dimaksud adalah sistem diagnosa penyakit yang disertai demam dengan menggunakan metode Naive Bayes Classifier. Sistem aplikasi diagnosa penyakit yang disertai demam ini berbasis Expert System atau sistem pakar dengan tampilan aplikasi berupa website.

Adapun alur yang akan dibuat dalam aplikasi sistem pakar ini dimulai pada halaman diagnosa, yaitu dengan pengisian data diri pasien dan pemilihan gejala-gejala yang dikeluhkan. Selanjutnya untuk melihat hasil diagnosa akan ditampilkan pada halaman hasil diagnosa. Dengan alur yang sederhana ini, diharapkan akan mudah dalam penggunaanya sehingga diharapkan dapat membantu penderita atau orang awam mengetahui jenis penyakit dan penyembuhannya berdasarkan gejala-gejala yang dikeluhkan.

\section{TINJAUAN PUSTAKA DAN LANDASAN TEORI}

\subsection{Tinjauan Pustaka}

Pada penelitian yang berjudul "Sistem Pakar Diagnosa Penyakit Sapi Potong Dengan Metode Nä̈ve Bayes". Fokus penelitian ini membahas sistem pakar diagnosa penyakit sapi potong menggunakan inferensi Nä̈ve Bayes dalam menghitung hasil diagnosanya. Alur proses kerja aplikasi dimulai dengan cara memasukkan gejala klinis yang muncul pada ternak. Melalui gejala klinis tersebut akan dilakukan perhitungan dengan metode Naive Bayes untuk mendapatkan nilai probabilitas posterior setiap class jenis penyakit ternak. Pada penelitian ini menggunakan 20 jenis gejala dan 11 jenis penyakit serta data uji sebanyak 26 kasus dengan tingkat akurasi sebesar 96,15\% (Dewi, Soebroto, \& Furqon, 2015).

Penelitian dengan judul "Sistem Pakar Diagnosis Penyakit Mata Menggunakan Nä̈ve Bayes Classifier". Penelitian ini membahas sistem pakar penyakit pada mata dengan menggunakan 52 gejala dan 15 penyakit mata, serta 12 pasien penderita sakit mata sebagai data uji aplikasi. Proses diagnosa aplikasi dalam penelitian ini melalui dua tahapan yaitu pertama pasien akan mengisi data gejala yang dikeluhkan selanjutnya sistem secara otomatis akan menampilkan hasil diagnosa melalui perhitungan nä̈ve bayes classifier. Dari hasil percobaan, diperoleh prosentasi keberhasilan sebesar 83\% (Setiawan \& Ratnasari, 2014).

Penelitian dengan judul "Sistem Pakar Diagnosa Awal Kanker Serviks Menggunakan Metode Naive Bayes Berbasis Android". Penelitian ini membahas identifikasi diagnosa kanker serviks dengan metode Nä̈ve Bayes. Aplikasi yang dibuat ini berbasis sistem pakar dengan fokus penelitian dibidang kesehatan yaitu meneliti gejala penyakit kanker serviks pada wanita. Fungsi dari penelitian ini adalah untuk membantu penderita kanker serviks menentukan kemungkinan terjangkit kanker serviks sehingga dapat segera mendapatkan penanganan lebih lanjut dari medis. Aplikasi Sistem Pakar Diagnosa Awal Kanker Serviks Berbasis Android telah diujikan ke 20 orang penderita kanker serviks dan erosi portio dan diperoleh tingkat akurasi sebesar $85 \%$. (Arisandi \& Izzuddin, 2016).

Penelitian dengan judul "Implementasi Nä̈ve Bayes Classifier Dalam Sistem Pakar Defisiensi Nutrisi Pada Balita". Fokus penelitian ini menggunakan metode inferensi Nä̈ve Bayes Classifier dengan menentukan beberapa defisiensi nutrisi berdasarkan tabel antropometri berupa tinggi badan, berat badan, dan umur selanjutnya memilih gejala tambahan untuk mempersempit hasil klasifikasi. Tujuan penelitian ini untuk mengidentifikasi defisiensi nutrisi pada balita sebagai upaya untuk membantu pemerintah dalam memenuhi kebutuhan gizi balita di Kota Kendari. Dalam penelitian ini menggunakan data uji 4 jenis penyakit, 30 jenis gejala, dan 20 pasien dengan tingkat akurasi 90\% (Putra, Aksara, \& Ramadhan, 2016).

Penelitian dengan judul "Sistem Pakar Penentuan Penyakit Gagal Jantung Menggunakan Metode Nä̈ve Bayes Classifier". Penelitian ini menggunakan metode inferensi naïve bayes classifier, dengan fokus penelitian mendeteksi jenis penyakit jantung berdasarkan gejala yang di input. Data uji yang digunakan berupa input 16 gejala yaitu Dysnoea, Reduced Exercise, Tolerance, Orthopnea, Nocturnal Cough, Wheeze, Ankle Swelling, Anorexia, Lerhargy, Minum banyak sesak, Tachyardia, Hepatomegaly, Cachexia, 
Ascites, Heart Rate, Resprator Rule dan 4 hasil output yaitu DC Dextra, DC Sinestra, DC Kongesif, dan negatif DC. Berdasarkan hasil uji coba yang dilakukan dengan menggunakan 100 data, didapatkan hasil bahwa sistem pakar penentuan penyakit gagal jantung dengan metode naïve bayes classifier ini mampu menghasilkan akurasi rata-rata sebesar $83 \%$ (Sulaksono \& Darsono, 2015).

\subsection{Landasan Teori}

\subsubsection{Sistem Pakar}

Sistem pakar adalah salah satu cabang dari Artificial Intelligence (AI) yang membuat penggunaan secara luas knowledge yang khusus untuk penyelesaian masalah tingkat manusia yang pakar. Seorang pakar adalah orang yang mempunyai keahlian dalam bidang tertentu, yaitu pakar yang mempunyai knowledge atau kemampuan khusus yang orang lain tidak mengetahui atau mampu dalam bidang yang dimilikinya (Arhami, 2005).

Sedangkan dalam pengertian yang lain, sistem pakar adalah program komputer yang menirukan penalaran seorang pakar dengan keahlian pada suatu wilayah pengetahuan tertentu. Seorang pakar bukan hanya menangani permasalahan berdasarkan algoritma, tetapi terkadang harus menangani permasalahan yang sulit kita pahami dan hanya dapat diatasi oleh seorang pakar berdasarkan pengetahuan dan pengalamannya. Oleh karena itu, sistem pakar dibuat bukan berdasarkan algoritma tertentu tetapi berdasarkan basis pengetahuan dan aturan (Kusrini, 2006).

\subsubsection{Demam}

Kriteria suhu untuk demam adalah kenaikan suhu tubuh $1^{\circ} \mathrm{C}$ diatas nilai rata-rata suhu tubuh normal. Sebagai contoh bila seorang anak suhu tubuh rerata normal di ketiak adalah $36,5^{\circ} \mathrm{C}$ maka ia akan disebut demam bila suhu tubuh yang diukur di ketiak adalah $37,5^{\circ} \mathrm{C}$ atau lebih. Dalam perhitungan ini, skala suhu yang digunakan adalah skala celcius. (Handy, 2016).

Demam adalah suatu kondisi disaat suhu badan menjadi lebih tinggi daripada biasanya, atau suhu diatas $38^{\circ} \mathrm{C}$. meskipun demam merupakan gejala penyakit tertentu, pada umumnya demam terjadi karena tubuh sedang melawan infeksi. Beberapa gejala yang ditimbulkan akibat demam antara lan: menggigil, panas dan dingin bergantian, lemas, berkeringat, dan wajah kelihatan memerah (Sugani \& Priandarini, 2010).

Demam juga menunjukan adanya gejalagejala penyakit serius seperti: influenza, HIV, malaria, demam berdarah, demam thyfoid, gastroenteritis, kanker dan lain-lain. Oleh karena itu, sangat dianjurkan untuk segera ke dokter jika mengalami demam yang disertai gejala seperti lemas, muntah, diare, sesak nafas, bintik merah, ataupun gejala-gejala lainnya (Sugani \& Priandarini, 2010).

Salah satu jenis penyakit dengan gejala demam yang sering kita temui dalam kehidupan sehari-hari adalah demam thyfoid, masyarakat umum biasa mengenal penyakit ini dengan sebutan demam tipus. Jenis demam yang terjadi pada penyakit ini dapat menular, proses penularan dapat melalui makanan dan minuman yang tercemar kuman Salmonella Typhi. Setelah kuman masuk ke tubuh, biasanya akan timbul gejala penyakit dalam masa inkubasi setelah 7-21 hari (Djauzi, 2009).

\subsubsection{Naive Bayes Classifier}

Nä̈ve Bayes Classifier merupakan pengklasifikasi probabilitas sederhana berdasarkan pada teorema Bayes. Keuntungan Nä̈ve Bayes Classifier adalah hanya membutuhkan sejumlah kecil data pelatihan untuk memperkirakan parameter (sarana dan varians dari variabel) dalam proses klasifikasi. Dalam prosesnya, Naïve Bayes Classifier mengasumsikan bahwa ada atau tidaknya suatu fitur pada suatu kelas tidak berhubungan dengan ada atau tidaknya fitur lain di kelas yang sama (Setiawan \& Ratnasari, 2014).

Semua klasifikasi Bayes merupakan klasifikasi statistik yang dapat digunakan untuk memprediksi probabilitas keanggotaan suatu class. Untuk klasifikasi Bayes sederhana dikenal sebagai naüveBayesianClassifier yang dapat diasumsikan bahwa efek dari suatu nilai atribut sebuah kelas yang diberikan adalah bebas dari atribut-atribut lain. Asumsi ini disebut class conditionalindependence yang dibuat untuk memudahkan dalam perhitungan (Sulaksono \& Darsono, 2015).

Metode Naive Bayes Classifier. Merupakan model penyederhanaan dari teorema bayes yang cocok untuk pengklasifikasian jenis penyakit. Berikut ini rumus persamaan pada nä̈ve bayes classifier (Putra, Aksara, \& Ramadhan, 2016).

$\mathrm{P}\left(a_{i} \mid v_{j}\right) \quad=\frac{n_{c}+m_{p}}{\mathrm{n}+\mathrm{m}}$ 
Keterangan:

$\mathrm{n}_{\mathrm{c}} \quad=$ jumlah record pada data yang $\mathrm{v}=\mathrm{v}_{\mathrm{j}}$ dan $\mathrm{a}=\mathrm{a}_{\mathrm{i}}$

$\mathrm{m}_{\mathrm{p}} \quad=1 /$ banyaknya jenis penyakit

$\mathrm{m} \quad=$ jumlah parameter gejala

$\mathrm{n} \quad=$ jumlah record pada data yang $\mathrm{v}=\mathrm{v}_{\mathrm{j}}$ tiap class

untuk menyelesaikan persamaan tersebut, dilakukan tahapan-tahapan sebagai berikut:

(1) Menentukan nilai $n_{c}$ untuk setiap class, (2) Menghitung nilai $P\left(a_{i} \mid v_{j}\right)$ dan menghitung nilai $\mathrm{P}\left(\mathrm{v}_{\mathrm{j}}\right)$, (3) Menghitung $\mathrm{P}\left(\mathrm{a}_{\mathrm{i}} \mid \mathrm{v}_{\mathrm{j}}\right) \times \mathrm{P}\left(\mathrm{v}_{\mathrm{j}}\right)$ untuk tiap $\mathrm{v}$, dan (4) Menentukan hasil klasifikasi yaitu v yang memiliki hasil perkalian yang terbesar.

\section{METODOLOGI PENELITIAN}

\subsection{Alur Penelitian}

Alur penelitian dalam proses pembuatan aplikasi sistem pakar diagnosa penyakit yang disertai demam ditunjukan dengan bagan alir pada gambar 1 .

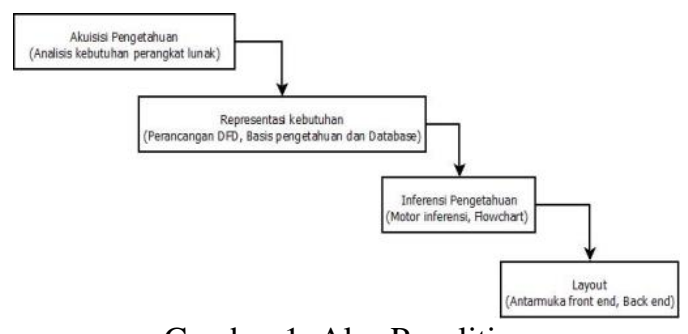

Gambar 1. Alur Penelitian

\subsection{Perancangan DFD}

Data Flow Diagram merupakan diagram alir data yang menggambarkan bagaimana data diproses oleh sistem.

Data Flow Diagram berorientasi pada alur data dengan konsep dekomposisi yang dapat digunakan untuk penggambaran analisa maupun rancangan sistem supaya mudah dikomunikasikan antara profesional sistem kepada pemakai maupun pembuat program

\subsection{Perancangan ERD}

Entity Relationship Diagram (ERD) pada sistem pakar diagnosa penyakit yang disertai gejala demam, ditunjukan pada gambar 3.

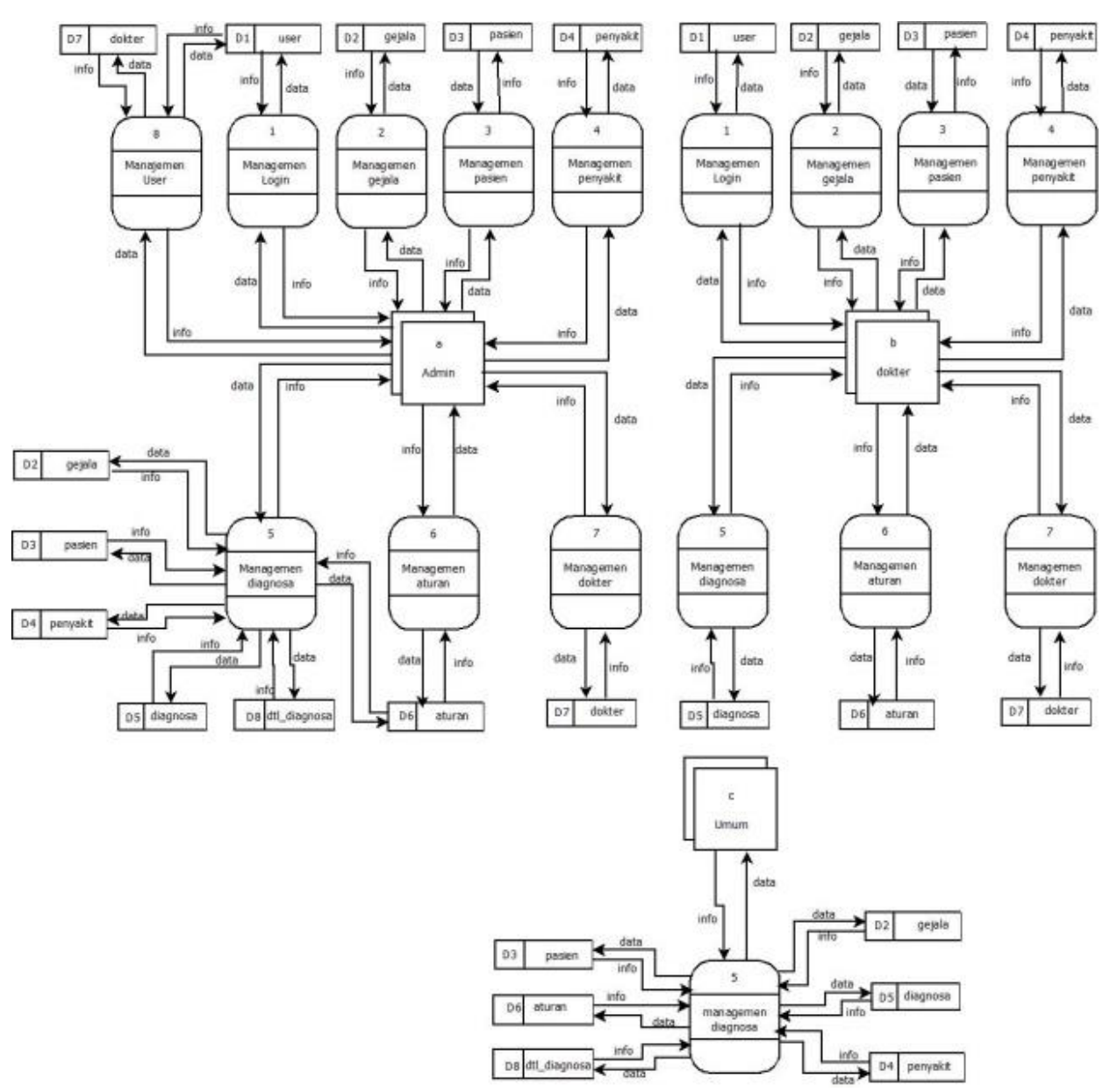

Gambar 2. Data Flow Diagram 


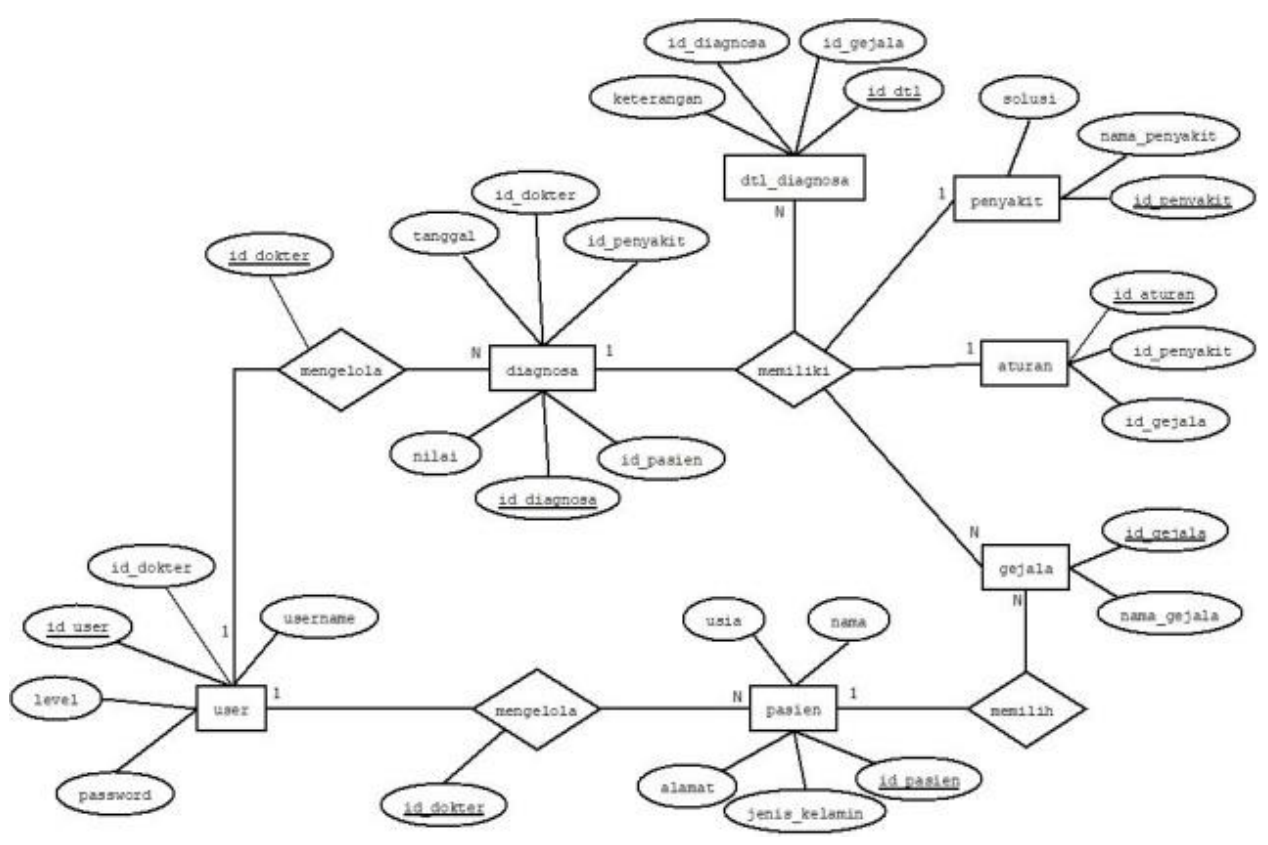

Gambar 3. Entity Relationship Diagram

\subsection{Motor Inferensi}

Motor inferensijalannya sistem pakar diagnosa penyakit yang disertai demam dengan metode Naive Bayes Classifier, dapat dilihat pada gambar4.

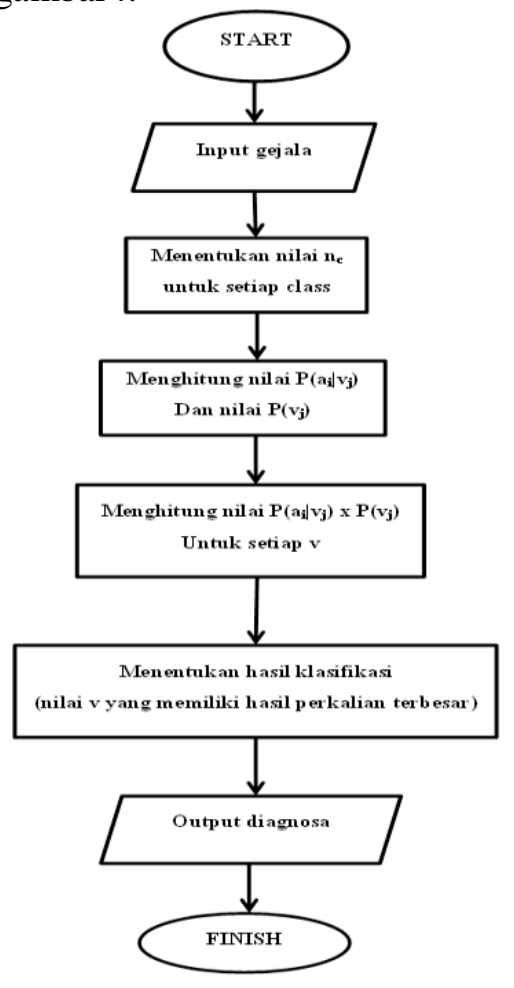

Gambar 4. Motor Inferensi

\subsection{Implementasi Naive Bayes Classifier}

Dalam implementasi Naive bayes classifier dilakukan proses inferensi yang mengacu pada data rekam medis pasien, selanjutnya untuk mempermudah proses inferensi setiap gejala penyakit yang ada diubah dalam bentuk kode gejala.

Tabel 1. Data Kode Gejala

\begin{tabular}{|l|l|l|}
\hline No & \multicolumn{1}{|c|}{ Nama Pasien } & \multicolumn{1}{|c|}{ Gejala } \\
\hline 1. & Samino & $\begin{array}{l}\text { GJ001, GJ002, } \\
\text { GJ024 }\end{array}$ \\
\hline 2. & Supriyati & $\begin{array}{l}\text { GJ001, GJ002, } \\
\text { GJ003 }\end{array}$ \\
\hline 3. & Nur Malikah & $\begin{array}{l}\text { GJ001, GJ003, } \\
\text { GJ002, GJ004 }\end{array}$ \\
\hline 4. & Untung Subargo & $\begin{array}{l}\text { GJ001, GJ002, } \\
\text { GJ005, GJ006 }\end{array}$ \\
\hline 5. & Sony & $\begin{array}{l}\text { GJ001, GJ002, } \\
\text { GJ008, GJ007 }\end{array}$ \\
\hline 6. & Riski Saputra & $\begin{array}{l}\text { GJ001, GJ003, } \\
\text { GJ018, GJ009 }\end{array}$ \\
\hline 7. & Jemino & $\begin{array}{l}\text { GJ001, GJ003, } \\
\text { GJ009, GJ025 }\end{array}$ \\
\hline 8. & Yunus & $\begin{array}{l}\text { GJ001, GJ003, } \\
\text { GJ019, GJ009 }\end{array}$ \\
\hline 9. & Tarwandi & $\begin{array}{l}\text { GJ001, GJ003, } \\
\text { GJ018, GJ009 }\end{array}$ \\
\hline 10. & Tugiran & $\begin{array}{l}\text { GJ001, GJ003, } \\
\text { GJ009, GJ018 }\end{array}$ \\
\hline 11. & Afifa & $\begin{array}{l}\text { GJ001, GJ003, } \\
\text { GJ022, GJ024 }\end{array}$ \\
\hline 12. & Galih Fema & $\begin{array}{l}\text { GJ001, GJ023, } \\
\text { GJ008 }\end{array}$ \\
\hline
\end{tabular}




\begin{tabular}{|c|c|c|}
\hline No & Nama Pasien & Gejala \\
\hline 13. & Nandhita Fema & $\begin{array}{l}\text { GJ001, GJ025, } \\
\text { GJ022, GJ024 }\end{array}$ \\
\hline 14. & Faizin & $\begin{array}{l}\text { GJ001, GJ003, } \\
\text { GJ008, GJ022 }\end{array}$ \\
\hline 15. & Himatuz & $\begin{array}{l}\text { GJ001, GJ023, } \\
\text { GJ003 }\end{array}$ \\
\hline 16. & Priyono & $\begin{array}{l}\text { GJ001, GJ020, } \\
\text { GJ018 }\end{array}$ \\
\hline 17. & Deva Apriyanto & $\begin{array}{l}\text { GJ001, GJ020, } \\
\text { GJ018 }\end{array}$ \\
\hline 18. & Pramiliati & $\begin{array}{l}\text { GJ001, GJ020, } \\
\text { GJ018, GJ003 }\end{array}$ \\
\hline 19. & Galih Said & $\begin{array}{l}\text { GJ001, GJ020, } \\
\text { GJ018 }\end{array}$ \\
\hline 20. & Tumar & $\begin{array}{l}\text { GJ001, GJ020, } \\
\text { GJ018 }\end{array}$ \\
\hline 21. & Ainum & $\begin{array}{l}\text { GJ001, GJ003, } \\
\text { GJ010, GJ011 }\end{array}$ \\
\hline 22. & Anisa Latifah & $\begin{array}{l}\text { GJ001, GJ004, } \\
\text { GJ011, GJ012 }\end{array}$ \\
\hline 23. & Aulia Azzahra & $\begin{array}{l}\text { GJ001, GJ003, } \\
\text { GJ011, GJ013 }\end{array}$ \\
\hline 24. & Ratri & $\begin{array}{l}\text { GJ001, GJ003, } \\
\text { GJ012, GJ024, } \\
\text { GJ013, GJ011 }\end{array}$ \\
\hline 25. & Lukman $\mathrm{H}$ & $\begin{array}{l}\text { GJ001, GJ004, } \\
\text { GJ011, GJ010 }\end{array}$ \\
\hline 26. & Anisa Isnaeni & $\begin{array}{l}\text { GJ001, GJ016, } \\
\text { GJ010 }\end{array}$ \\
\hline 27. & Sobri K & $\begin{array}{l}\text { GJ001, GJ010, } \\
\text { GJ024, GJ016, } \\
\text { GJ017 }\end{array}$ \\
\hline
\end{tabular}

Selanjutnya, sebagai contoh untuk proses inferensi diambil satu data pasien secara acak sebagai sampel data uji.

Tabel 2. Sampel Data Uji

\begin{tabular}{|c|c|c|}
\hline No & Nama Pasien & Gejala \\
\hline 7. & Jemino & $\begin{array}{c}\text { GJ001, GJ003, } \\
\text { GJ009, GJ025 }\end{array}$ \\
\hline
\end{tabular}

Keterangan:

$\begin{array}{ll}\text { GJ001 } & =\text { Demam } \\ \text { GJ003 } & =\text { Sakit kepala } \\ \text { GJ009 } & \text { Lidah kotor } \\ \text { GJ025 } & =\text { Nafsu makan menurun }\end{array}$

Berdasarkan Tabel 2. Sampel Data Uji, diketahui bahwa pasien atas nama Jemino dengan gejala yang dikeluhkan yaitu Demam, Sakit kepala, Lidah kotor, dan Nafsu makan menurun. Sehingga proses inferensi dengan Naive Bayes Classifier dapat dihitung sebagai berikut:

1. Menentukan nilai $\mathrm{n}_{\mathrm{c}}$ untuk setiap class, diketahui:

$\mathrm{n}=1$

$\mathrm{p}=1 / 6=0.166666666666667$

$\mathrm{m}=25$

a. Penyakit ke-1, Typus (Thypoid)

Gejala 1 (GJ001), $\mathrm{n}_{\mathrm{c}}=1$

Gejala $2(\mathrm{GJ} 003), \mathrm{n}_{\mathrm{c}}=1$

Gejala $3(\mathrm{GJ} 009), \mathrm{n}_{\mathrm{c}}=1$

Gejala $4\left(\right.$ GJ025), $n_{c}=1$

b. Penyakit ke-2, ISPA

Gejala 1 (GJ001), $\mathrm{n}_{\mathrm{c}}=1$

Gejala $2(\mathrm{GJ} 003), \mathrm{n}_{\mathrm{c}}=1$

Gejala $3(\mathrm{GJ} 009), \mathrm{n}_{\mathrm{c}}=0$

Gejala $4(\mathrm{GJ} 025), \mathrm{n}_{\mathrm{c}}=0$

c. Penyakit ke-3, Cacar Air

Gejala $1(\mathrm{GJ} 001), \mathrm{n}_{\mathrm{c}}=1$

Gejala $2\left(\right.$ GJ003), $n_{\mathrm{c}}=1$

Gejala $3\left(\right.$ GJ009), $\mathrm{n}_{\mathrm{c}}=0$

Gejala $4(\mathrm{GJ} 025), \mathrm{n}_{\mathrm{c}}=1$

d. Penyakit ke-4, Diare

Gejala $1(\mathrm{GJ} 001), \mathrm{n}_{\mathrm{c}}=1$

Gejala $2(\mathrm{GJ} 003), \mathrm{n}_{\mathrm{c}}=1$

Gejala $3(\mathrm{GJ} 009), \mathrm{n}_{\mathrm{c}}=0$

Gejala $4(\mathrm{GJ} 025), \mathrm{n}_{\mathrm{c}}=1$

e. Penyakit ke-5, Gondongan (Mumps)

Gejala 1 (GJ001), $\mathrm{n}_{\mathrm{c}}=1$

Gejala $2(\mathrm{GJ} 003), \mathrm{n}_{\mathrm{c}}=0$

Gejala 3 (GJ009), $\mathrm{n}_{\mathrm{c}}=0$

Gejala $4(\mathrm{GJ} 025), \mathrm{n}_{\mathrm{c}}=1$

f. Penyakit ke-6, Radang Amandel (Tonsilitis)

Gejala $1(\mathrm{GJ} 001), \mathrm{n}_{\mathrm{c}}=1$

Gejala $2(\mathrm{GJ} 003), \mathrm{n}_{\mathrm{c}}=1$

Gejala $3(\mathrm{GJ} 009), \mathrm{n}_{\mathrm{c}}=0$

Gejala $4(\mathrm{GJ} 025), \mathrm{n}_{\mathrm{c}}=1$

2. Menghitung nilai $P \quad\left(a_{i} \mid l \quad v_{j}\right)$ dan menghitung nilai $P\left(v_{\mathrm{j}}\right)$

a. Penyakit ke-1, Typus (Thypoid)

$$
\begin{aligned}
& \mathrm{P}(1 \mid \mathrm{X})=\frac{1+25 \times 0.16666666666667}{1+25}=0.1987 \\
& \mathrm{P}(2 \mid \mathrm{X})=\frac{1+25 \times 0.16666666666667}{1+25}=0.1987
\end{aligned}
$$


$\mathrm{P}(3 \mid \mathrm{X})=\frac{1+25 \times 0.16666666666667}{1+25}=0.1987$

$\mathrm{P}(4 \mid \mathrm{X})=\frac{1+25 \times 0.16666666666667}{1+25}=0.1987$

b. Penyakit ke-2, ISPA

$\mathrm{P}(1 \mid \mathrm{X})=\frac{1+25 \times 0.16666666666667}{1+25}=0.1987$

$\mathrm{P}(2 \mid \mathrm{X})=\frac{1+25 \times 0.16666666666667}{1+25}=0.1987$

$\mathrm{P}(3 \mid \mathrm{X})=\frac{0+25 \times 0.16666666666667}{1+25}=0.1602$

$\mathrm{P}(4 \mid \mathrm{X})=\frac{0+25 \times 0.16666666666667}{1+25}=0.1602$

c. Penyakit ke-3, Cacar Air

$\mathrm{P}(1 \mid \mathrm{X})=\frac{1+25 \times 0.16666666666667}{1+25}=0.1987$

$\mathrm{P}(2 \mid \mathrm{X})=\frac{1+25 \times 0.16666666666667}{1+25}=0.1987$

$\mathrm{P}(3 \mid \mathrm{X})=\frac{0+25 \times 0.16666666666667}{1+25}=0.1602$

$\mathrm{P}(4 \mid \mathrm{X})=\frac{1+25 \times 0.16666666666667}{1+25}=0.1987$

d. Penyakit ke-4, Diare

$$
\begin{aligned}
& P(1 \mid X)=\frac{1+25 \times 0.16666666666667}{1+25}=0.1987 \\
& P(2 \mid X)=\frac{1+25 \times 0.16666666666667}{1+25}=0.1987 \\
& P(3 \mid X)=\frac{0+25 \times 0.16666666666667}{1+25}=0.1602 \\
& P(4 \mid X)=\frac{1+25 \times 0.16666666666667}{1+25}=0.1987
\end{aligned}
$$

e. Penyakit ke-5, Gondongan (Mumps)

$$
\begin{aligned}
& P(1 \mid X)=\frac{1+25 \times 0.16666666666667}{1+25}=0.1987 \\
& P(2 \mid X)=\frac{0+25 \times 0.166666666666667}{1+25}=0.1602 \\
& P(3 \mid X)=\frac{0+25 \times 0.16666666666667}{1+25}=0.1602 \\
& P(4 \mid X)=\frac{1+25 \times 0.16666666666667}{1+25}=0.1987
\end{aligned}
$$

f. Penyakit ke-6, Radang Amandel (Tonsilitis)

$$
\begin{aligned}
& P(1 \mid X)=\frac{1+25 \times 0.16666666666667}{1+25}=0.1987 \\
& P(2 \mid X)=\frac{1+25 \times 0.16666666666667}{1+25}=0.1987 \\
& P(3 \mid X)=\frac{0+25 \times 0.16666666666667}{1+25}=0.1602 \\
& P\left(4 \mid X=\frac{1+25 \times 0.16666666666667}{1+25}=0.198\right.
\end{aligned}
$$

3. Menghitung nilai $P\left(a_{i} \mid v_{j}\right) \times P\left(v_{j}\right)$ untuk tiap v

a. Penyakit ke-1, Typus (Thypoid)

$\mathrm{P}(\mathrm{X})$ x $[\mathrm{P}(1 \mid \mathrm{X})$ x $\mathrm{P}(2 \mid \mathrm{X})$ x $\mathrm{P}(3 \mid \mathrm{X})$ x $\mathrm{P}(4 \mid \mathrm{X})]$ $=0.16666666666667 \times[0.1987 \times 0.1987 \times$

$$
0.1987 \times 0.1987]
$$

$=0.00025989452553217$

b. Penyakit ke-2, ISPA $\mathrm{P}(\mathrm{X}) \times \mathrm{P}(1 \mid \mathrm{X}) \times \mathrm{P}(2 \mid \mathrm{X}) \times \mathrm{P}(3 \mid \mathrm{X})$ x $\mathrm{P}(4 \mid \mathrm{X})]$ $=0.16666666666667 \times[0.1987 \times 0.1987 \times$

$0.1602 \times 0.1602]$

$=0.00016902609620979$

c. Penyakit ke-3, Cacar Air

$\mathrm{P}(\mathrm{X}) \times[\mathrm{P}(1 \mid \mathrm{X})$ x $\mathrm{P}(2 \mid \mathrm{X})$ x $\mathrm{P}(3 \mid \mathrm{X})$ x $\mathrm{P}(4 \mid \mathrm{X})]$ $=0.16666666666667 \times[0.1987 \times 0.1987 \times$

$$
0.1602 \times 0.1987]
$$

$=0.00020959235930014$

d. Penyakit ke-4, Diare

$\mathrm{P}(\mathrm{X})$ x $[\mathrm{P}(1 \mid \mathrm{X})$ x $\mathrm{P}(2 \mid \mathrm{X}) \times \mathrm{P}(3 \mid \mathrm{X})$ x $\mathrm{P}(4 \mid \mathrm{X})]$ $=0.16666666666667 \times[0.1987 \times 0.1987 \times$

$$
0.1602 \times 0.1987]
$$

$$
=0.00020959235930014
$$

e. Penyakit ke-5, Gondongan (Mumps) $\mathrm{P}(\mathrm{X})$ x $[\mathrm{P}(1 \mid \mathrm{X})$ x $\mathrm{P}(2 \mid \mathrm{X})$ x $\mathrm{P}(3 \mid \mathrm{X})$ x $\mathrm{P}(4 \mid \mathrm{X})]$ $=0.16666666666667 \times[0.1987 \times 0.1602 \times$ $0.1602 \times 0.1987]$

$=0.00016902609620979$

f. Penyakit ke-6, Radang Amandel (Tonsilitis)

$\mathrm{P}(\mathrm{X}) \times[\mathrm{P}(1 \mid \mathrm{X})$ x $\mathrm{P}(2 \mid \mathrm{X})$ x $\mathrm{P}(3 \mid \mathrm{X}) \times \mathrm{P}(4 \mid \mathrm{X})]$ $=0.16666666666667 \times[0.1987 \times 0.1987 \times$ $0.1602 \times 0.1987]$

$=0.00020959235930014$

4. Menentukan hasil klasifikasi yaitu v yang memiliki hasil perkalian terbesar.

Tabel 3. Hasil Klasifikasi

\begin{tabular}{|c|c|}
\hline Nama Penyakit & Nilai v \\
\hline Typus (Thypoid) & 0.00025989452553217 \\
\hline
\end{tabular}




\begin{tabular}{|l|c|}
\hline Nama Penyakit & \multicolumn{1}{|c|}{ Nilai v } \\
\hline ISPA & 0.00016902609620979 \\
\hline Cacar Air & 0.00020959235930014 \\
\hline Diare & 0.00020959235930014 \\
\hline $\begin{array}{l}\text { Gondongan } \\
\text { (Mumps) }\end{array}$ & 0.00016902609620979 \\
\hline $\begin{array}{l}\text { Radang Amandel } \\
\text { (Tonsilitis) }\end{array}$ & 0.00020959235930014 \\
\hline
\end{tabular}

Berdasarkan dari hasil perhitungan, diperoleh nilai $\mathrm{v}$ maksimum sebesar 0.00025989452553217 . Sehingga pasien atas nama Jemino terdeteksi mengidap penyakit Typus (Thypoid).

\section{PEMBAHASAN}

\subsection{Validasi Hasil}

Proses validasi hasil bertujuan untuk membandingkan data hasil inferensi pada Sistem dengan data pada Rekam Medis Pasien, validasi hasil ditunjukan pada Tabel 4.

Tabel 4. Validasi Hasil

\begin{tabular}{|c|c|c|c|c|}
\hline \multirow[t]{2}{*}{ No } & \multirow[t]{2}{*}{ Pasien } & $\begin{array}{c}\text { Hasil Dari } \\
\text { Sistem }\end{array}$ & Hasil RM & \multirow[t]{2}{*}{ Validasi } \\
\hline & & \multicolumn{2}{|c|}{ Penyakit } & \\
\hline 1 & Samino & $\begin{array}{c}\text { Typus } \\
\text { (Thypoid) }\end{array}$ & ISPA & Tidak \\
\hline 2 & Supriyati & ISPA & ISPA & Sesuai \\
\hline 3 & $\begin{array}{c}\text { Nur } \\
\text { Malikah }\end{array}$ & ISPA & ISPA & Sesuai \\
\hline 4 & $\begin{array}{c}\text { Untung } \\
\text { Subargo }\end{array}$ & ISPA & ISPA & Sesuai \\
\hline 5 & Sony & ISPA & ISPA & Sesuai \\
\hline 6 & $\begin{array}{c}\text { Riski } \\
\text { Saputra }\end{array}$ & $\begin{array}{c}\text { Typus } \\
\text { (Thypoid) }\end{array}$ & \begin{tabular}{|c|} 
Typus \\
(Thypoid)
\end{tabular} & Sesuai \\
\hline 7 & Jemino & $\begin{array}{c}\text { Typus } \\
\text { (Thypoid) }\end{array}$ & $\begin{array}{c}\text { Typus } \\
\text { (Thypoid) }\end{array}$ & Sesuai \\
\hline 8 & Yunus & $\begin{array}{c}\text { Typus } \\
\text { (Thypoid) }\end{array}$ & $\begin{array}{c}\text { Typus } \\
\text { (Thypoid) }\end{array}$ & Sesuai \\
\hline 9 & Tarwandi & $\begin{array}{c}\text { Typus } \\
\text { (Thypoid) }\end{array}$ & $\begin{array}{c}\text { Typus } \\
\text { (Thypoid) }\end{array}$ & Sesuai \\
\hline 10 & Tugiran & $\begin{array}{c}\text { Typus } \\
\text { (Thypoid) }\end{array}$ & $\begin{array}{c}\text { Typus } \\
\text { (Thypoid) }\end{array}$ & Sesuai \\
\hline 11 & Afifa & Cacar Air & Cacar Air & Sesuai \\
\hline 12 & $\begin{array}{l}\text { Galih } \\
\text { Fema }\end{array}$ & Cacar Air & Cacar Air & Sesuai \\
\hline 13 & $\begin{array}{l}\text { Nandhita } \\
\text { Fema }\end{array}$ & Cacar Air & Cacar Air & Sesuai \\
\hline 14 & Faizin & Cacar Air & Cacar Air & Sesuai \\
\hline 15 & Himatuz & Cacar Air & Cacar Air & Sesuai \\
\hline 16 & Priyono & Diare & Diare & Sesuai \\
\hline 17 & $\begin{array}{c}\text { Deva } \\
\text { Apriyanto }\end{array}$ & Diare & Diare & Sesuai \\
\hline 18 & Pramiliati & Diare & Diare & Sesuai \\
\hline 19 & Galih Said & Diare & Diare & Sesuai \\
\hline 20 & Tumar & Diare & Diare & Sesuai \\
\hline 21 & Ainum & $\begin{array}{l}\text { Radang } \\
\text { Amandel }\end{array}$ & $\begin{array}{l}\text { Radang } \\
\text { Amandel }\end{array}$ & Sesuai \\
\hline
\end{tabular}

\begin{tabular}{|c|c|c|c|c|}
\hline \multirow[t]{3}{*}{ No } & \multirow[t]{3}{*}{ Pasien } & $\begin{array}{l}\text { Hasil Dari } \\
\text { Sistem }\end{array}$ & Hasil RM & \multirow[t]{2}{*}{ Validasi } \\
\hline & & \multicolumn{2}{|c|}{ Penyakit } & \\
\hline & & (Tonsilitis) & (Tonsilitis) & \\
\hline 22 & $\begin{array}{c}\text { Anisa } \\
\text { Latifah }\end{array}$ & $\begin{array}{c}\text { Radang } \\
\text { Amandel } \\
\text { (Tonsilitis) }\end{array}$ & $\begin{array}{c}\text { Radang } \\
\text { Amandel } \\
\text { (Tonsilitis) }\end{array}$ & Sesuai \\
\hline 23 & $\begin{array}{c}\text { Aulia } \\
\text { Azzahra }\end{array}$ & $\begin{array}{c}\text { Radang } \\
\text { Amandel } \\
\text { (Tonsilitis) }\end{array}$ & $\begin{array}{c}\text { Radang } \\
\text { Amandel } \\
\text { (Tonsilitis) }\end{array}$ & Sesuai \\
\hline 24 & Ratri & $\begin{array}{c}\text { Radang } \\
\text { Amandel } \\
\text { (Tonsilitis) }\end{array}$ & $\begin{array}{c}\text { Radang } \\
\text { Amandel } \\
\text { (Tonsilitis) }\end{array}$ & Sesuai \\
\hline 25 & Lukman H & $\begin{array}{c}\text { Radang } \\
\text { Amandel } \\
\text { (Tonsilitis) }\end{array}$ & $\begin{array}{c}\text { Radang } \\
\text { Amandel } \\
\text { (Tonsilitis) }\end{array}$ & Sesuai \\
\hline 26 & $\begin{array}{c}\text { Anisa } \\
\text { Isnaeni }\end{array}$ & $\begin{array}{l}\text { Gondongan } \\
\text { (Mumps) }\end{array}$ & $\begin{array}{l}\text { Gondongan } \\
\text { (Mumps) }\end{array}$ & Sesuai \\
\hline 27 & Sobri K & $\begin{array}{c}\text { Gondongan } \\
\text { (Mumps) }\end{array}$ & $\begin{array}{l}\text { Gondongan } \\
\text { (Mumps) }\end{array}$ & Sesuai \\
\hline
\end{tabular}

Berdasarkan tabel 4. Validasi Hasil, dari 27 sampel data terdapat 1 pasien atas nama Samino yang mengalami ketidakcocokan hasil antara sistem dan rekam medis. Pada sistem, pasien atas nama Samino terdeteksi penyakit Typus sedangkan pada rekam medis dia merupakan penderita ISPA. Perbedaan hasil ini dapat terjadi karena minimnya gejala yang dikeluhkan oleh pasien.

\section{KESIMPULAN}

Dari penelitian yang telah dilakukan, kesimpulan yang dapat diperoleh adalah sebagai berikut:

1. Berdasarkan 27 data pemeriksaan pasien yang diambil,dan diuji dengan sistem serta telah divalidasi oleh pakar (dokter) diperoleh tingkat kesesuaian sebesar 96,3\%.

2. Sistem yang dirancang dengan metode Naive Bayes Classifier dapat digunakan untuk membantu dalam mendeteksi jenis penyakit yang disertai gejala demam.

\section{UCAPAN TERIMA KASIH}

Dengan selesainya penelitian ini penulis mengucapkan banyak terimakasih kepada semua pihak yang telah membantu dan memberikan dukungan.

\section{DAFTAR PUSTAKA}

Arhami, M. (2005). Konsep Dasar Sistem Pakar. Yogyakarta: Andi.

Arisandi, Q. T., \& Izzuddin, A. (2016). Sistem Pakar Diagnosa Awal Kanker Serviks Menggunakan Metode Naive Bayes 
Berbasis Android. Jurnal Ilmiah Ilmu-

Ilmu Teknik.

Dewi, I. C., Soebroto, A. A., \& Furqon, M. T. (2015). Sistem Pakar Diagnosa Penyakit Sapi Potong Dengan Metode Naive Bayes. Journal of Environmental Engineering \& Sustainable Technology, Vol. 2, Nomor 2.

Djauzi, S. (2009). Raih Kembali Kesehatan. Jakarta: Buku Kompas.

Handy, F. (2016). A-Z Penyakit Langganan Anak. Jakarta: Pustaka Bunda.

Kusrini. (2006). Sistem Pakar, Teori Dan Aplikasi. Yogyakarta: Andi.

Putra, H. M., Aksara, L. F., \& Ramadhan, R. (2016). Implementasi Naive Bayes Classifier Dalam Sistem Pakar
Defisiensi Nutrisi Pada Balita.

SemanTIK, Vol. 2, Nomor 1.

Setiawan, W., \& Ratnasari, S. (2014). Sistem

Pakar Diagnosis Penyakit Mata

Menggunakan Naive Bayes Classifier.

Seminar Nasional Sains dan

Teknologi.

Sugani, S., \& Priandarini, L. (2010). Cara

Cerdas Untuk Sehat. Jakarta:

TransMedia.

Sulaksono, J., \& Darsono. (2015). Sistem

Pakar Penentuan Penyakit Gagal

Jantung Menggunakan Metode Naive

Bayes Classifier. Seminar Nasional

Teknologi Informasi Dan Multimedia.

Yuliarti, N. (2009). A To Z Foot Supplement. Yogyakarta: Andi Offset. 
10 Jurnal Multimedia \& Artificial Intelligence, Volume 2, Nomor 2, Agustus 2018 